STUDIA Z PRAWA WYZNANIOWEGO

Tom $24-2021$

DOI: https://doi.org/10.31743/spw.10676

MICHALINA DUDA-HYZ*

\title{
OPODATKOWANIE PRZYCHODÓW \\ Z TYTUŁU KOSZERYZACJI ŻYWNOŚCI ZRYCZAŁTOWANYM PODATKIEM DOCHODOWYM OD PRZYCHODÓW OSÓB DUCHOWNYCH
}

Taxation of income from koshering food with the flat rate income tax on the income of the clergy

Streszczenie: Celem artykułu jest analiza przepisów normujących zryczałtowany podatek dochodowy od przychodów osób duchownych w kontekście opodatkowania wynagrodzenia rabinów i podrabinów za czynności związane z koszeryzacją żywności. Badania przeprowadzone na potrzeby niniejszej publikacji opierają się na następujących tezach badawczych. Po pierwsze, w przypadku czerpania przez rabinów i podrabinów dochodów z tytułu koszeryzacji żywności spełnione są przesłanki podmiotowa i funkcjonalna. Podatnikiem jest bowiem osoba duchowna, zaś podejmowane przez nią w ramach koszeryzacji czynności stanowią formę funkcji o charakterze duszpasterskim. Po drugie, o możliwości skorzystania z uproszczonej formy opodatkowania przesądza status jednostki organizacyjnej, w ramach której zatrudnione są osoby duchowne oraz sposób ukształtowania stosunku prawnego stanowiącego podstawę wypłaty wynagrodzenia.

Słowa kluczowe: koszeryzacja; podatek dochodowy od osób fizycznych; duchowni; zryczałtowany podatek dochodowy od przychodów osób fizycznych

Abstract: The aim of the article was to analyse the legal provisions regulating the flat rate income tax on the income of the clergy with respect to the taxation of remuneration of rabbis and assistant rabbis for activities related to koshering food. The research conducted for the purposes of this publication is based on

* Dr hab., prof. UO, Katedra Prawa Gospodarczego i Finansowego, Wydział Prawa i Administracji, Uniwersytet Opolski, Pl. Kopernika 11a, 45-040 Opole, e-mail: michalina.duda-hyz@uni.opole.pl. ORCID: 0000-0001-7058-3481. 
the following hypotheses. First, in the case of rabbis and assistant rabbis who draw income from koshering food, the conditions pertaining to the subject and function are fulfilled, as the taxpayer is a member of the clergy, and the activities undertaken by such a person in the course of kosherization have a pastoral function. Second, the possibility of using a simplified form of taxation is determined by the status of the organizational unit within which members of the clergy are employed and the manner in which the legal relationship constituting the basis for payment of remuneration is formed.

Key words: kosherization; personal income tax; clergy; flat rate income tax on the income of natural persons

\section{WPROWADZENIE}

Zryczałtowany podatek dochodowy od przychodów osób duchownych jest instytucją o bogatych tradycjach. Genezy tej formy opodatkowania można bowiem upatrywać już w treści przepisów zarządzenia Ministerstwa Finansów z 1957 r. ${ }^{1}$ Jest to również instytucja, której poświęcono stosunkowo dużo uwagi w literaturze przedmiotu ${ }^{2}$. Konstrukcja ryczałtu od przychodów osób duchownych w obowiązującym kształcie została wprowadzona do polskiego systemu prawnego w drodze ustawy z 1998 r. o zryczałtowanym podatku dochodowym od niektórych przychodów osiąganych przez osoby fizyczne ${ }^{3}$. Symptomatyczny jest przy tym fakt, że w przeciwieństwie do przepisów normujących opodatkowanie dochodów osób fizycznych na zasadach ogólnych, regulacje dotyczące tej formy opodatkowania nie uległy istotnym zmianom. Przepisy normujące zryczałtowany podatek dochodowy od przychodów osób duchownych stosunkowo rzadko stanowią również przedmiot sporów pomiędzy podatnikami a organami podatkowymi. Niemniej jednak, z uwagi na to, że konstrukcja ryczałtu została opraco-

1 Szerzej zob. Stanisławski 2001, 67-79; Jurowiec 2014, 215-220.

2 Zob. Porożyński 2005, 4-16; Gierasimiuk 2005, 161-171; Walencik 2008, 231-253; Patyk 2008, 211-250; Zieliński 2013, 98-113; Krzyżak 2015, 96-107; Wojewoda-Buraczyńska 2017, 165-174.

3 Ustawa z dnia 20 listopada 1998 r. o zryczałtowanym podatku dochodowym od niektórych przychodów osiąganych przez osoby fizyczne, Dz. U. z 2019 r., poz. 43, dalej: ustawa o zryczałtowanym podatku dochodowym. 
wana z uwzględnieniem specyfiki i struktury organizacyjnej dominującego w Polsce Kościoła Rzymskokatolickiego, wątpliwości interpretacyjne może rodzić zastosowanie obowiązujących regulacji w odniesieniu do duchownych innych związków wyznaniowych.

W myśl przepisów ustawy o zryczałtowanym podatku dochodowym od niektórych przychodów osiąganych przez osoby fizyczne podatek dochodowy w formie ryczałtu uiszczają osoby duchowne osiągające przychody $\mathrm{z}$ opłat otrzymywanych $\mathrm{w}$ związku z pełnionymi funkcjami o charakterze duszpasterskim ${ }^{4}$. Korzystanie z powyższej formy opodatkowania jest zatem uzależnione od spełnienia trzech warunków. Pierwszym jest posiadanie statusu osoby duchownej, drugim pełnienie funkcji o charakterze duszpasterskim, trzecim osiąganie przychodów z opłat związanych ze sprawowaniem tych funkcji.

Celem artykułu jest analiza przepisów normujących zryczałtowany podatek dochodowy od przychodów osób duchownych w kontekście opodatkowania wynagrodzenia rabinów i podrabinów za czynności związane z koszeryzacją żywności. W związku z powyższym w kolejnych częściach opracowania ocenie poddano wskazane wyżej przesłanki opodatkowania w formie ryczałtu od osób duchownych. Badania przeprowadzone na potrzeby niniejszej publikacji służą weryfikacji następujących hipotez badawczych. Po pierwsze, w przypadku czerpania przez rabinów i podrabinów dochodów z tytułu koszeryzacji żywności spełnione są przesłanki podmiotowa i funkcjonalna. Podatnikiem jest bowiem osoba duchowna, zaś podejmowane przez nią w ramach koszeryzacji czynności stanowią funkcje o charakterze duszpasterskim. Po drugie, o możliwości skorzystania z uproszczonej formy opodatkowania przesądza sposób ukształtowania stosunku prawnego stanowiącego podstawę wypłaty wynagrodzenia.

\section{STATUS OSOBY DUCHOWNEJ}

Ustawa o zryczałtowanym podatku dochodowym nie zawiera definicji legalnej pojęcia duchownego ani nie odsyła w powyższym zakresie do przepisów innych ustaw. Definicji legalnych terminów „duchowny” czy „oso-

4 Art. 42 ustawy o zryczałtowanym podatku dochodowym. 
ba duchowna" nie formułują również przepisy tzw. ustaw wyznaniowych. W doktrynie prawa wyznaniowego zgodnie wyrażane jest jednak stanowisko, iż w świetle ustawy o gwarancjach wolności sumienia i wyznania ${ }^{5}$ status osoby duchownej na gruncie prawa polskiego ma osoba, która została ustanowiona duchownym zgodnie z normami prawa wewnętrznego kościoła lub innego związku wyznaniowego ${ }^{6}$. Należy również podkreślić, że przepisy ustawy o zryczałtowanym podatku dochodowym explicite stanowią, iż zryczałtowany podatek dochodowy od przychodów osób duchownych opłacają osoby duchowne prawnie uznanych wyznań7 ${ }^{7}$ W ujęciu podmiotowym prawo do skorzystania z preferencyjnej formy opodatkowania zależy zatem od tego, czy danej osobie, w świetle przepisów prawa wewnętrznego podmiotu mającego w Polsce status prawny związku wyznaniowego, przysługuje status duchownego. Powyższa teza znajduje również potwierdzenie w orzecznictwie sądowym. W wyroku z dnia 19 września 2000 r. Naczelny Sąd Administracyjny stwierdził, że jeżeli kościół lub inny związek wyznaniowy przewiduje tworzenie stanowisk osób duchownych, to sposób ich powoływania, odwoływania oraz kompetencje winien określać statut. Sąd zwrócił również uwagę, iż wobec braku definicji pojęcia duchownego w ustawodawstwie dotyczącym kościołów i innych związków wyznaniowych dla uznania określonej osoby za duchownego konieczne jest wnikliwe zapoznanie się z zasadami funkcjonowania kościoła lub związku wyznaniowego ${ }^{8}$. Duchownym w rozumieniu przepisów ustawy o zryczałtowanym podatku dochodowym jest zatem osoba, która została ustanowiona duchownym zgodnie z normami prawa wewnętrznego kościoła lub innego związku wyznaniowego o uregulowanej sytuacji prawnej ${ }^{9}$. Mimo tego, że powyższa kwestia nie była szerzej rozpatrywana w kontekście prawnopodatkowym, uzasadnione wydaje się również stanowisko, iż duchownym w powyższym znaczeniu może być wyłącznie osoba należąca do danego związku wyznaniowego, która wyróżnia się

5 Ustawa z dnia 17 maja 1989 r. o gwarancjach wolności sumienia i wyznania, tekst jedn. Dz. U. z 2017 r., poz. 1153.

Zob. Stanisz 2011, 290; Pieron 2017, 157.

7 Art. 2 ust. 2 ustawy o zryczałtowanym podatku dochodowym.

8 Zob. wyrok NSA z dnia 19 września 2000 r., III SA 1411/00, LEX nr 47198. Zob. także wyrok WSA w Szczecinie z dnia 14 czerwca 2018 r., II SA/Sz 461/18, LEX nr 2510782.

9 Zob. Babiarz 2012, el. 
spośród ogółu wyznawców danej religii tym, iż została powołana do stałego organizowania i sprawowania kultu religijnego ${ }^{10}$.

Sytuację prawną gmin wyznaniowych żydowskich określa ustawa o stosunku Państwa do gmin wyznaniowych żydowskich w Rzeczypospolitej Polskiej ${ }^{11}$. W myśl powołanego aktu gminy żydowskie rządzą się w swoich sprawach własnym prawem wewnętrznym, określającym w szczególności organizację gmin żydowskich ${ }^{12}$. Obowiązujące obecnie prawo wewnętrzne, tj. Prawo wewnętrzne wyznaniowej wspólnoty żydowskiej w Rzeczypospolitej Polskiej, zostało uchwalone 15 stycznia 2006 r. ${ }^{13}$ przez Walne Zebranie Związku Gmin Wyznaniowych Żydowskich w porozumieniu z Radą Religijną Związku Gmin ${ }^{14}$. Prawo to określa całokształt spraw związanych z wewnętrzną organizacją i funkcjonowaniem wyznaniowej społeczności żydowskiej w Polsce, zwanej „Wspólnotą”. W ramach odrębnego rozdziału unormowano kwestię duchownych Wspólnoty. I tak, w myśl powołanego dokumentu, duchownymi we Wspólnocie są naczelny rabin RP oraz rabini gmin. Prawo wewnętrzne wyróżnia nadto kategorię podrabinów oraz innych osób pełniących funkcje duchownych zgodnie z uchwałą Rady Religijnej Związku Gmin ${ }^{15}$. Rabini i podrabini są przedstawicielami Wspólnoty w zakresie zagadnień religijnych, rytualnych

10 Powyższa teza została wyrażona przez Sąd Najwyższy na tle przepisów ustawy z dnia 21 listopada 1967 r. o powszechnym obowiązku obrony Rzeczypospolitej Polskiej. Zob. uchwała (7) SN z dnia 6 maja 1992 r., I KZP 1/92, Legalis nr 27676. Stanowisko, iż osoby duchowne powinny wykonywać lub być uprawnione do wykonywania takich czynności związanych z kultem religijnym, które ze względu na reguły funkcjonowania związku wyznaniowego nie mogą być wykonywane przez każdego członka wspólnoty, wyrażano również w doktrynie prawa podatkowego w odniesieniu do statusu duchowego w podatku dochodowym. Zob. Huchla 2001, el.

11 Ustawa z dnia 20 lutego 1997 r. o stosunku Państwa do gmin wyznaniowych żydowskich w Rzeczypospolitej Polskiej, tekst jedn. Dz. U. z 2014 r., poz. 1798, dalej: ustawa o stosunku Państwa do gmin wyznaniowych żydowskich.

12 Art. 3 ust. 2 ustawy o stosunku Państwa do gmin wyznaniowych żydowskich.

13 Prawo wewnętrzne wyznaniowej wspólnoty żydowskiej w Rzeczypospolitej Polskiej z dnia 15 stycznia 2006 r., 15 Tewet 5766/stycznia 2006 r., https://warszawa.jewish. org.pl/pl/o-nas/zarzad-gminy/ [dostęp: 13.05.2020], dalej: Prawo wewnętrzne wyznaniowej wspólnoty żydowskiej w RP.

14 Szerzej zob. Zieliński 2011, 28-29.

15 Art. 46 Prawa wewnętrznego wyznaniowej wspólnoty żydowskiej w RP. 
i kultowych ${ }^{16}$. W świetle powyższych regulacji nie budzi zatem wątpliwości fakt, iż na gruncie przepisów o podatku dochodowym od osób fizycznych status duchownego przysługuje zarówno rabinom, jak i podrabinom.

\section{PEŁNIENIE FUNKCJI DUSZPASTERSKIEJ}

W myśl przepisów ustawy o zryczałtowanym podatku dochodowym z preferencyjnej formy opodatkowania jaką jest ryczałt od przychodów osób duchownych mogą korzystać tylko te osoby duchowne, które pełnią funkcje o charakterze duszpasterskim. Ustawa nie precyzuje, co należy rozumieć przez „funkcje o charakterze duszpasterskim”. W doktrynie prawa podatkowego trafnie zwraca się uwagę, że jest to pojęcie nieostre ${ }^{17}$. Wyrażane jest również stanowisko, iż niejednoznaczne określenie przedmiotu opodatkowania stwarza ryzyko nadużywania konstrukcji ryczałtu ${ }^{18}$. W powszechnym języku polskim termin ,duszpasterski” oznacza 'właściwy duszpasterzowi, związany z duszpasterzem - kapłanem jako duchowym opiekunem wiernych'. Z kolei „duszpasterz” to 'kapłan jako duchowy opiekun wiernych; kapłan odpowiedzialny za życie religijne określonej kościelnej jednostki organizacyjnej (diecezji, dekanatu, parafii itp.) lub określonego środowiska (robotników, studentów, młodzieży itp.); czasem też: ksiądz, kapłan w ogóle' ${ }^{19}$. W płaszczyźnie ogólnego języka polskiego wyrażenie „funkcja duszpasterska” co do zasady jest zatem utożsamiane z funkcją właściwą duszpasterzom, w szczególności ze sprawowaniem duchowej opieki nad wiernymi. Z kolei zastosowanie systemowych dyrektyw wykładni prowadzi do konkluzji, iż zakres znaczeniowy wyrażenia „funkcja o charakterze duszpasterskim” obejmuje funkcje, jakie sprawują: proboszczowie, wikariusze, osoby duchowne kierujące jednostkami kościelnymi posiadającymi samodzielną administrację w wydzielonej części parafii, rektorzy i inne osoby duchowne kierujące jednostkami kościelny-

16 Art. 48 Prawa wewnętrznego wyznaniowej wspólnoty żydowskiej w RP.

17 Zob. P. Borszowski 2012, el.

18 Zob. Wojewoda-Buraczyńska 2017, 170.

19 Zgółkowa (red.) 1996, 389-390. Zob. także Dubisz (red.) 2003, 722; Dunaj (red.) 1996, 207. 
mi posiadającymi samodzielną administrację bez wydzielonej części parafii, a także osoby duchowne niepełniące funkcji proboszczów, wikariuszy i rektorów, które osiągają przychody z misji, rekolekcji oraz innych posług religijnych ${ }^{20}$. Na tle powyższych uwag nasuwają się następujące wnioski.

Po pierwsze, konstrukcja ryczałtu od przychodów osób duchownych nawiązuje do zadań oraz hierarchicznego ustroju Kościoła Rzymskokatolickiego, czego wyrazem jest m.in. odwołanie do stanowisk proboszczów i wikariuszy czy nazw kościelnych jednostek organizacyjnych ${ }^{21}$. Odniesienie powyższych regulacji do sytuacji prawnej osób duchownych innych wyznań wymaga zatem uwzględnienia specyfiki funkcjonowania oraz struktury organizacyjnej danego związku wyznaniowego.

Po drugie, skoro w świetle przepisów ustawy o gwarancjach wolności sumienia i wyznania ustanawianie osób duchownych i przypisywanie im zadań zostało pozostawione autonomicznej decyzji poszczególnych związków wyznaniowych, określenie rodzajów funkcji i zadań jakie pełnią różne osoby duchowne wymaga zapoznania się z zasadami funkcjonowania oraz treścią prawa wewnętrznego danego związku wyznaniowego. Oznacza to, że zrekonstruowanie zakresu znaczeniowego wyrażenia ,funkcje o charakterze duszpasterskim" wyłącznie w oparciu o analizę przepisów ustawy o zryczałtowanym podatku dochodowym nie jest możliwe.

Po trzecie, zadania przypisywane duchownym na gruncie przepisów prawa wewnętrznego mogą wykraczać poza formy aktywności bezpośrednio związane z odprawianiem nabożeństw i duchową opieką nad wiernymi. W konsekwencji zakres znaczeniowy nazwy „funkcje o charakterze duszpasterskim" obejmuje również inne zadania, np. zarządcze, administracyjne, koordynacyjne czy pracę charytatywną 22 .

Po czwarte, $\mathrm{z}$ opodatkowania $\mathrm{w}$ formie ryczałtu mogą korzystać również takie osoby duchowne, które nie kierują jednostkami kościelnymi posiadającymi samodzielną administrację ani nie pełnią funkcji proboszczów,

20 Art. 43 i art. 45 ustawy o zryczałtowanym podatku dochodowym.

21 Szerzej zob. Walencik 2008, 233-236. Na temat genezy i ewolucji tej formy opodatkowania Stanisławski 2001, 67-79; Jurowiec 2014, 215-220.

22 Szerzej zob. np. Dyda 2018, 64-66; Słowikowska 2010, 191-212; Filak 2018, 142-150; Bielecki 2018, 133-139. 
wikariuszy i rektorów, bądź funkcji do nich porównywalnych ${ }^{23}$. Zakresem rzeczonej preferencji objęto bowiem również duchownych osiągających przychody z misji, rekolekcji oraz innych posług religijnych. Nie ma przy tym znaczenia, czy dochody te są osiągane stale czy sporadycznie. Użycie w treści przepisu nieostrego wyrażenia ,inne posługi religijne” zdaje się świadczyć o tym, że intencją prawodawcy było umożliwienie opodatkowania $\mathrm{w}$ preferencyjnej formie także przychodów $\mathrm{z}$ tytułu sprawowania funkcji religijnych specyficznych dla danego wyznania i niemających swego odpowiednika w funkcjach sprawowanych przez duchownych wyznań chrześcijańskich. Jednocześnie należy zauważyć, że wyrażenie „,posługi religijne" jest na gruncie dyrektyw językowych jednoznaczne. Oznacza bowiem posługi "mające związek z religią, dotyczące religii, zespołu wierzeń ${ }^{24}$. Do posług o charakterze religijnym należy zatem zaliczyć wyłącznie te funkcje i zadania duchownych, które są czynnościami o charakterze religijnym ${ }^{25}$. W konsekwencji posługami religijnymi w powyższym znaczeniu nie będą formy aktywności związane wyłącznie z przypisanymi osobom duchownym zadaniami administracyjnymi czy zarządczymi. Reasumując należy stwierdzić, iż zakres znaczeniowy wyrażenia „funkcje o charakterze duszpasterskim" obejmuje również takie czynności, które stanowią posługi religijne w świetle przepisów prawa wewnętrznego danego związku wyznaniowego lecz nie są porównywalne z żadnymi posługami charakterystycznymi dla wyznań chrześcijańskich.

Ustawa o stosunku Państwa do gmin wyznaniowych żydowskich w Rzeczypospolitej Polskiej potwierdza w płaszczyźnie ustawowej konstytucyjne gwarancje mojżeszowego związku wyznaniowego w zakresie organizowania i sprawowania kultu publicznego oraz udzielania posług religijnych zgodnie z prawem wewnętrznym ${ }^{26}$. W treści powołanego

23 Zob. wyrok WSA w Opolu z dnia 30 października 2013 r., I SA/Op 530/13, LEX nr 1587693.

24 Zob. Dunaj (red.) 1996, 941; Zgółkowa (red.) 2002, 416; Dubisz (red.) 2003, 63.

25 W doktrynie prawa wyznaniowego zwraca się uwagę, że posługi religijne mogą mieć zarówno postać kultu publicznego, jak i prywatnego. Posługę religijną definiuje się jako czynność o charakterze religijnym osoby upoważnionej przez związek wyznaniowy na rzecz innej osoby lub osób wyrażających życzenie skorzystania z takiej czynności. Zob. Zieliński 2012, el.

26 Art. 9 ust. 1 ustawy o stosunku Państwa do gmin wyznaniowych żydowskich. 
aktu zawarto przepis stanowiący explicite, iż w celu realizacji prawa do sprawowania obrzędów i czynności rytualnych związanych z kultem religijnym, gminy żydowskie dbają o zaopatrzenie w koszerną żywność, o stołówki i łaźnie rytualne oraz o ubój rytualny ${ }^{27}$. W prawie polskim problematyka uboju rytualnego była szeroko rozpatrywana w kontekście konstytucyjnych gwarancji wolności sumienia i wyznania ${ }^{28}$. W treści uzasadnienia do wyroku wydanego 10 grudnia 2014 r. Trybunał Konstytucyjny wskazał jednoznacznie, iż: „Współcześnie ubój rytualny w dalszym ciągu jest czynnością o charakterze liturgicznym, mimo iż prowadzony jest w rzeźniach. Z uwagi na wypełnianie w drodze uboju rytualnego nakazów religii, jak również liturgiczny charakter samego uboju, czynności z nim związane, niezależnie od skali uboju, nadal podporządkowane są normom prawa religijnego i zwyczajowego"29. Trybunał podkreślił nadto, iż w polskim porządku prawnym religijny charakter uboju rytualnego potwierdza przytoczony wyżej przepis ustawy o stosunku Państwa do gmin wyznaniowych żydowskich, wskazując na istotne znaczenie, jakie dla społeczności żydowskiej mają specyficzne czynności właściwe judaizmowi ${ }^{30}$.

Prawo do prowadzenia uboju rytualnego zgodnie z przepisami religijnymi było również rozpatrywane na gruncie prawa międzynarodowego, w kontekście prawa do uzewnętrzniania swego wyznania przez czynności rytualne ${ }^{31}$, a także na gruncie prawa unijnego. W wyroku wydanym 27 czerwca 2000 r. Europejski Trybunał Praw Człowieka w Strasburgu stwierdził, iż ubój rytualny, jak wskazuje jego nazwa, jest czynnością rytualną. Ma on dostarczyć członkom żydowskiej społeczności mięsa zwierząt zabitych zgodnie z przepisami religijnymi, co

27 Art. 9 ust. 2 ustawy o stosunku Państwa do gmin wyznaniowych żydowskich.

28 Szerzej zob. Łętowska, Namysłowska, Grochowski, Wiewiórowska-Domagalska 2013a, 13-18; Łętowska, Namysłowska, Grochowski, Wiewiórowska-Domagalska 2013b, 4-8; Brzozowski 2013, 47-56; Kaczmarczyk 2014, 56-63.

29 Zob. wyrok TK z dnia 10 grudnia 1014 r., K 52/13, Legalis nr 1123153.

30 Tamże.

31 Art. 9 Konwencji o Ochronie Praw Człowieka i Podstawowych Wolności sporządzonej w Rzymie dnia 4 listopada 1950 r., zmienionej następnie Protokołami nr 3, 5 i 8 oraz uzupełnionej Protokołem nr 2, Dz. U. z 1993 r. Nr 61, poz. 284. 
jest zasadniczym elementem praktykowania religii żydowskiej ${ }^{32}$. Z kolei w wyroku z dnia 17 grudnia 2020 r. Trybunał Sprawiedliwości Unii Europejskiej orzekł, iż szczególne metody uboju wymagane przez obrzędy religijne i poszanowanie religijnych nakazów żywieniowych wchodzą w zakres wolności religii i mogą być uznane za publiczne uzewnętrznianie przekonań religijnych w rozumieniu europejskiej Konwencji o ochronie praw człowieka i podstawowych wolności oraz Karty Praw Podstawowych Unii Europejskiej33. Tezę, iż ubój rytualny stanowi obrzęd religijny Trybunał wyraził również w odniesieniu do czynności uboju praktykowanego w czasie muzułmańskiego święta ofiarowania ${ }^{34}$. W świetle powyższych uwag nie powinien budzić wątpliwości fakt, iż podejmowane przez duchownych czynności związane z koszeryzacją żywności, jako mające charakter liturgiczny, mogą być uznane za „inne posługi religijne” w rozumieniu przepisów ustawy o zryczałtowanym podatku dochodowym od niektórych przychodów osiąganych przez osoby fizyczne.

Jak już zaznaczono, zrekonstruowanie zakresu znaczeniowego wyrażenia „funkcje o charakterze duszpasterskim” wymaga uwzględnienia przepisów prawa wewnętrznego danego związku wyznaniowego. Zgodnie $\mathrm{z}$ treścią Prawa wewnętrznego wyznaniowej wspólnoty żydowskiej w RP do zakresu obowiązków rabinów i podrabinów należy m.in. nadzór nad ubojem rytualnym i obiektami produkcji, rozpowszechnianiem i konsumpcją żywności koszernej ${ }^{35}$. Nadzór nad ubojem rytualnym jest zatem formą posługi religijnej, która należy do zakresu obowiązków duchownych Wspólnoty. Co więcej, prawo wewnętrzne stanowi wyraźnie, iż czynności związane z rzeczonym nadzorem należą do wyłącznej kompetencji

32 Zob. wyrok Wielkiej Izby Europejskiego Trybunału Praw Człowieka w Strasburgu z dnia 27 czerwca 2000 r. w sprawie Cha'are Shalom ve Tsedek przeciwko Francji, skarga $\mathrm{nr}$ 27417/95, https://hudoc.echr.coe.int/eng\#\{\%22itemid\%22:[\%22001-58738\%22]\} [dostęp: 15.08.2020]. Szerzej zob. Nowicki 2005, 932.

33 Zob. wyrok Trybunału Sprawiedliwości Unii Europejskiej z dnia 17 grudnia 2020 r. w sprawie C-336/19, wniosek o wydanie orzeczenia w trybie prejuducjalnym złożony przez Grondwettelijk Hof, ECLI:EU:C:2020:1031.

34 Zob. wyrok Trybunału Sprawiedliwości Unii Europejskiej z dnia 29 maja 2018 r. w sprawie C-426/16, Liga van Moskeeën en Islamitische Organisaties Provincie Antwerpen VZW i in. przeciwko Vlaams Gewest, ECLI:EU:C:2018:335.

35 Art. 49 ust. 1 pkt 2 Prawa wewnętrznego wyznaniowej wspólnoty żydowskiej w RP. 
rabinów oraz osób przez nich desygnowanych ${ }^{36}$. Sprawowanie nadzoru nad ubojem rytualnym i obiektami produkcji, rozpowszechnianiem i konsumpcją żywności koszernej może być zatem uznane za pełnienie funkcji o charakterze duszpasterskim w rozumieniu przepisów ustawy o zryczałtowanym podatku dochodowym.

\section{OSIĄGANIE PRZYCHODÓW Z OPŁAT ZWIĄZANYCH ZE SPRAWOWANIEM FUNKCJI DUSZPASTERSKICH}

W myśl przepisów ustawy o zryczałtowanym podatku dochodowym podatek dochodowy w formie ryczałtu od przychodów osób duchownych opłacają osoby duchowne osiągające przychody z „opłat otrzymywanych w związku z pełnionymi funkcjami o charakterze duszpasterskim". Ustawa, obok ograniczenia podmiotowego, odnoszącego się do statusu podatnika, statuuje zatem również ograniczenie natury przedmiotowej, dotyczące źródła przychodów ${ }^{37}$. Możliwość zastosowania preferencyjnej formy opodatkowania nie dotyczy bowiem wszystkich przychodów osób duchownych pełniących funkcje duszpasterskie, lecz wyłącznie przychodów z opłat otrzymywanych w związku ze sprawowaniem tych funkcji. $\mathrm{Na}$ tle powyższej regulacji w doktrynie prawa podatkowego zgodnie wyrażane jest stanowisko, iż wszystkie pozostałe przychody podlegają opodatkowaniu na zasadach ogólnych ${ }^{38}$. W sytuacji, gdy osoby duchowne uzyskują dochody ze stosunku pracy i stosunków pokrewnych lub prowadzą działalność gospodarczą, podlegają opodatkowaniu tak jak inni podatnicy podatku dochodowego od osób fizycznych ${ }^{39}$. W przypadku osiągania przez

36 Art. 49 ust. 2 Prawa wewnętrznego wyznaniowej wspólnoty żydowskiej w RP.

37 Zob. Bartosiewicz, Kubacki 2011, el.

38 Zob. Etel 2002, 22; Stanisławski 2001, 67; Porożyński 2005, 5; Zieliński 2013, 103; Stanisz 2011, 296; Wojewoda-Buraczyńska 2017, 168.

39 Opodatkowanie na zasadach ogólnych dotyczy wszystkich dochodów uzyskiwanych z tytułu umowy o pracę, niezależnie od tego, czy umowa została zawarta z instytucją kościelną (np. kurią biskupią, seminarium duchownym) czy inną jednostką (np. szkołą, uczelnią, szpitalem, jednostką wojskową, zakładem karnym). Na zasadach ogólnych opodatkowane są również przychody z umów cywilnoprawnych. Szerzej zob. Świto 2010b, 99-100. 
duchownych przychodów ze źródeł innych niż wyżej wskazane, które nie są jednak związane z pełnionymi funkcjami duszpasterskimi, zastosowanie znajdują przepisy ustawy o podatku dochodowym od osób fizycznych dotyczące opodatkowania działalności wykonywanej osobiście bądź opodatkowania przychodów z tzw. innych źródeł ${ }^{40}$.

Ustawa o zryczałtowanym podatku dochodowym nie precyzuje, co należy rozumieć pod pojęciem opłat otrzymywanych w związku z pełnionymi funkcjami o charakterze duszpasterskim. W doktrynie prawa podatkowego słusznie zwraca się uwagę, że użycie w treści analizowanego przepisu terminu „opłata” nie jest do końca trafne ${ }^{41}$. W rzeczywistości przeważająca część otrzymywanych przez duchownych kwot nie ma bowiem charakteru opłat, lecz stanowi dobrowolne ofiary. Jak już zaznaczono, konstrukcja ryczałtu od osób duchownych została przyjęta w głównej mierze z uwagi na specyfikę uzyskiwania przychodów przez duchownych wyznania rzymskokatolickiego. W świetle przepisów Kodeksu Prawa Kanonicznego ${ }^{42}$ oraz kultywowanych w Polsce zwyczajów brak natomiast podstaw do tego, aby utożsamiać świadczenia wiernych związane z usługą duszpasterską z opłatą. Są to bowiem świadczenia dobrowolne, a potrzebujący nie mogą być pozbawieni pomocy sakramentów z racji ubóstwa $^{43}$. W literaturze przedmiotu trafnie zwraca się również uwagę, że obok względów praktycznych, to właśnie dobrowolny charakter ofiar, ich różna częstotliwość oraz wysokość są cechami, które uzasadniają zastosowanie ryczałtowej formy opodatkowania ${ }^{44}$. Do prawa i tradycji Kościoła rzymskokatolickiego nawiązuje także doktryna i judykatura w tych wypowiedziach, które stanowią próby doprecyzowania pojęcia przychodów z opłat otrzymywanych w związku z pełnionymi funkcjami duszpasterskimi. Wskazuje się, że powyższą kategorię tworzą ,wszelkiego rodzaju ofiary i darowizny za czynności wykonywane przez duchownych działających

40 Art. 13 i art. 20 ustawy z dnia 26 lipca 1991 r. o podatku dochodowym od osób fizycznych, tekst jedn. Dz. U. z 2019 r., poz. 1387.

41 Zob. Bartosiewicz, Kubacki 2011, el.; Patyk 2008, 228-229.

42 Codex Iuris Canonici auctoritate Ioannis Pauli PP. II promulgatus (25.01.1983), AAS 75 (1983), cz. II, s. 1-317; tekst polski: Kodeks Prawa Kanonicznego. Przekład polski zatwierdzony przez Konferencję Episkopatu Polski, Poznań: Pallotinum 1984.

43 Szerzej zob. Świto 2010a, 42-43.

44 Zob. Pieron 2017, 165. 
w tym charakterze, np. ofiary w związku z intencjami mszalnymi, ofiary otrzymywane podczas kolędy czy za udzielanie sakramentów"45. Należy również podkreślić, że w orzecznictwie sądów administracyjnych oraz organów podatkowych petryfikacji uległo kontrowersyjne stanowisko, iż cechą prawnie relewantną jest sama możliwość uzyskiwania przez osobę duchowną przychodów z opłat otrzymywanych w związku z pełnionymi funkcjami o charakterze duszpasterskim. W ocenie składów orzekających podatnik posiadający status podatnika zryczałtowanego jest zatem zobowiązany do zapłaty podatku niezależnie od tego, czy w danym okresie faktycznie osiągnął jakiekolwiek przychody ${ }^{46}$. Nie ma również znaczenia to, że uzyskane przez duchownego przychody zostały przeznaczone na rzecz kościelnej osoby prawnej lub innej instytucji ${ }^{47}$. Obowiązek podatkowy nie powstaje wówczas, gdy osoba duchowna w ogóle nie sprawuje funkcji duszpasterskich i tym samym nie ma nawet potencjalnej możliwości uzyskania $\mathrm{z}$ tego tytułu przychodów ${ }^{48}$.

Jak już zaznaczono, opodatkowaniu w formie zryczałtowanej podlegają wyłącznie przychody z opłat otrzymywanych w związku z pełnionymi funkcjami o charakterze duszpasterskim. W związku z powyższym, nawet jeśli dana osoba fizyczna jest duchownym i wypłacane są jej świadczenia, dla których podstaw prawnych można upatrywać w prawie wewnętrznym danego związku wyznaniowego, lecz świadczenia te nie są związane z pełnionymi funkcjami o charakterze duszpasterskim, preferencyjna forma opodatkowania nie znajduje zastosowania ${ }^{49}$. Ponieważ funkcje o charakterze duszpasterskim co do zasady są sprawowane na rzecz wiernych, w doktrynie

45 Zob. Bartosiewicz, Kubacki 2011, el.; wyrok WSA w Opolu z dnia 6 listopada 2013 r., I SA/Op 531/13, LEX nr 1391791.

46 Zob. wyrok NSA z dnia 20 kwietnia 2016 r., II FSK 2260/15, LEX nr 2021220; wyrok WSA w Opolu z dnia 8 kwietnia 2015 r., I SA/Op 24/15, LEX nr 1809009; interpretacja indywidualna Dyrektor Krajowej Informacji Skarbowej z dnia 18 kwietnia 2017 r., 1061-IPTPB4.4511.46.2017.2.SK, sip.mf.gov.pl. [dostęp: 20.05.2020].

47 Zob. wyrok NSA z dnia 20 kwietnia 2016 r., II FSK 491/14, LEX nr 2062782.

48 Zob. interpretacja indywidualna Naczelnika Urzędu Skarbowego Warszawa-Bemowo z dnia 28 kwietnia 2007 r., US.1431.DGII/415-16-38/07/HS, sip.mf.gov.pl [dostęp: 20.05.2020].

49 Zob. interpretacja indywidualna Dyrektor Izby Skarbowej w Poznaniu z dnia 27 października 2014 r., ILPB1/415-737/14-6/AA, sip.mf.gov.pl [dostęp: 20.05.2020]. 
prawa podatkowego wyrażono pogląd, iż podlegające ryczałtowi opłaty muszą pochodzić od osób, na rzecz których (chociażby pośrednio) działania te są podejmowane ${ }^{50}$. Nie ma natomiast znaczenia sposób poboru danych świadczeń ani stopień ich ekwiwalentności w stosunku do czynności wykonywanych w ramach sprawowania funkcji duszpasterskich ${ }^{51}$. Należy również podkreślić, że kwoty uzyskiwane przez duchownych z tytułu pełnienia funkcji duszpasterskich nie muszą im być przekazywane bezpośrednio przez wiernych, tak jak ma to miejsce m.in. w przypadku tzw. iura stolae, tj. ofiar składanych przez wiernych wyznania rzymskokatolickiego z racji udzielanych sakramentów i sakramentaliów. Świadczenia na rzecz osób duchownych mogą być wypłacane bądź realizowane przez jednostkę organizacyjną danego związku wyznaniowego (np. parafię czy organizację misyjną), jeżeli pochodzą ze świadczeń przekazywanych tej jednostce przez wiernych ${ }^{52}$. Jako przykład tego typu świadczeń można wskazać m.in. uposażenia oraz świadczenia o charakterze niepieniężnym (w postaci mieszkania służbowego) należne duchownym Kościoła Ewangelicko-Augsburskiego ${ }^{53}$. Warunkiem jest, aby stosunek prawny wiążący duchownego z daną jednostką nie miał charakteru pracowniczego $^{54}$. Jak już zaznaczono, dochody ze stosunku pracy podlegają bowiem opodatkowaniu na zasadach ogólnych, a stan duchowny pracownika nie skutkuje modyfikacją jego sytuacji prawnopodatkowej ${ }^{55}$.

W myśl przepisów Prawa wewnętrznego wyznaniowej wspólnoty żydowskiej w RP rabini i pozostałe osoby duchowne w Związku Gmin i gminach są zatrudniani na podstawie umowy o pracę wraz z zakresem

50 Zob. Huchla 2001, el.

51 Tamże.

52 Zob. interpretacja indywidualna Dyrektora Izby Skarbowej w Bydgoszczy z dnia 28 lutego 2008 r., ITPB2-415W-9/08; interpretacja indywidualna Dyrektora Izby Skarbowej w Bydgoszczy z dnia 12 sierpnia 2008 r., IITPB2/415-542/08/IB; sip.mf.gov.pl [dostęp: 20.05.2020].

53 Szerzej zob. Filak 2018, 145-149. Zob. także interpretacja indywidualna Dyrektora Izby Skarbowej w Bydgoszczy z dnia 15 listopada 2011 r., ITPB1/415-867/11/MR, sip. mf.gov.pl [dostęp: 20.05.2020].

${ }_{54}$ Zatrudnienie proboszcza przez parafię Ewangelicko-Augsburską do posług czysto religijnych nie ma charakteru pracowniczego. Zob. wyrok SN z dnia 5 maja 2010 r., I PK 201/09, LEX nr 1036598.

55 Zob. Stanisz 2011, 303; Stanisławski 2018, 248-249. 
obowiązków ${ }^{56}$. Stosunek prawny łączący Naczelnego Rabina RP oraz inne osoby duchowne z jednostkami organizacyjnymi Wspólnoty nie był rozpatrywany w doktrynie. Nie stanowił również przedmiotu orzeczeń sądowych, w szczególności wydanych w następstwie powództwa o ustalenie stosunku pracy. Szczegółowa analiza tego zagadnienia wykracza poza ramy niniejszego opracowania. Niemniej jednak, z uwagi na znaczenie powyższej przesłanki dla możliwości skorzystania z ryczałtowej formy opodatkowania, należy zwrócić uwagę na kilka kwestii.

Po pierwsze, w judykaturze i doktrynie prawa pracy utrwalone jest stanowisko, iż o wyborze rodzaju podstawy prawnej zatrudnienia decydują zainteresowane strony, przy czym kluczową rolę odgrywa w tym zakresie nie tyle przedmiot zobowiązania, co sposób jego realizacji ${ }^{57}$. Podkreśla się również, że w razie sporu na powyższym tle winno się uwzględniać całą specyfikę funkcjonowania podmiotu zatrudniającego ${ }^{58}$, którym w analizowanym przypadku jest wyznaniowa osoba prawna. Po drugie, prawo powszechnie obowiązujące nie określa, na jakiej podstawie prawnej rabini i podrabini wykonują czynności w ramach sprawowanych funkcji duszpasterskich. Zgodnie z treścią ustawy o stosunku Państwa do gmin wyznaniowych żydowskich organizowanie kultu publicznego oraz udzielanie posług religijnych podlega bowiem gminom żydowskim zgodnie z prawem wewnętrznym ${ }^{59}$. Po trzecie, w świetle przepisów ustawy o gwarancjach wolności sumienia i wyznania oraz ustawy o stosunku Państwa do gmin wyznaniowych żydowskich możliwe jest zatrudnianie osób duchownych na zasadach wewnątrzkościelnych. Przyznanie związkowi wyznaniowemu autonomii w zakresie wykonywania kultu religijnego oznacza bowiem również swobodę w określaniu statusu osób kult ten dobrowolnie wykonujących ${ }^{60}$.

Z treści Prawa wewnętrznego wyznaniowej wspólnoty żydowskiej w RP wynika, że Naczelny Rabin RP jest powoływany i odwoływany przez Radę Związku, natomiast rabini są zatrudniani przez zarządy gmin.

\footnotetext{
56 Art. 49 ust. 3 Prawa wewnętrznego wyznaniowej wspólnoty żydowskiej w RP.

57 Zob. Gersdorf 2014, teza 15 oraz powoływane tam orzecznictwo.

58 Tamże.

59 Art. 9 ust. 1 ustawy o stosunku Państwa do gmin wyznaniowych żydowskich.

60 Zob. wyrok SN z dnia 5 maja 2010 r., I PK 201/09, LEX nr 1036598.
} 
Jak już zaznaczono, akt ten stanowi expressis verbis, że rabini i pozostałe osoby duchowne w Związku Gmin i gminach są zatrudniani na podstawie umowy o pracę. $Z$ uwagi na brak informacji o dokumentach źródłowych kształtujących stosunek prawny pomiędzy osobami duchownymi a zatrudniającymi te osoby podmiotami nie sposób przesądzać o cechach tego stosunku. Warto jednak zaznaczyć, że w ocenie Sądu Najwyższego kwalifikacja prawna stosunku prawnego, dokonana przez strony przez nadanie umowie ustawowej nazwy, także jest jednym z elementów treści oświadczenia woli, który należy uwzględniać, dokonując interpretacji tego oświadczenia ${ }^{61}$. Fakt, iż rabini i podrabini opłacają podatek dochodowy od osób fizycznych w formie ryczałtu od przychodów osób duchownych zdaje się wskazywać, że stosunek zobowiązaniowy wiążący duchownych $\mathrm{z}$ daną jednostką nie ma charakteru pracowniczego, lecz osoby te świadczą pracę na podstawie prawa wewnętrznego. Wobec zastosowania $\mathrm{w}$ treści prawa wewnętrznego nazwy „umowa o pracę” kwestia ta może jednak budzić wątpliwości i winna podlegać rozstrzygnięciu w oparciu o postanowienia zawartych umów.

W 2020 r. do Krajowego Rejestru Sądowego została wpisana fundacja, której celem jest m.in. umożliwienie członkom społeczności żydowskiej swobodnego dostępu do koszernych produktów żywnościowych oraz promocja polskich produktów żywnościowych za granicą. Realizując wskazane cele fundacja prowadzi działalność gospodarczą w zakresie badań i analiz związanych z jakością żywności ${ }^{62}$. Ponieważ w świetle przepisów prawa wewnętrznego nadzór nad ubojem rytualnym należy do zakresu obowiązków duchownych Wspólnoty, rodzi się wątpliwość, czy w sytuacji gdyby wynagrodzenie za czynności związane z tym nadzorem wypłacała fundacja mogłyby one podlegać kwalifikacji jako „opłaty otrzymywane w związku z pełnionymi funkcjami o charakterze duszpasterskim".

Ustawa o zryczałtowanym podatku dochodowym nie określa wprost źródeł pochodzenia środków przekazywanych duchownym tytułem opłat w związku z pełnionymi funkcjami duszpasterskimi, ani nie wskazuje, jakie

${ }^{61}$ Szerzej zob. Gersdorf 2014, teza 17 oraz powoływane tam orzecznictwo.

${ }^{62}$ Zob. wpis do Krajowego Rejestru Sądowego nr 91034, https://www.imsig.pl/pozycja/2020/41/KRS/91034,FUNDACJA_KOSZER_POLSKA [dostęp: 10.06.2020]. 
podmioty mogą wypłacać świadczenia z tytułu sprawowania rzeczonych funkcji. Niewątpliwie opłaty (ofiary) te mogą być dokonywane bezpośrednio przez wiernych, a także przez osoby fizyczne, które nie są wyznawcami danej religii, ale dokonują darowizn (składają ofiary), np. doceniając społeczny czy kulturowy aspekt sprawowanych funkcji duszpasterskich. Jak już zaznaczono, opłaty za pełnienie funkcji o charakterze duszpasterskim mogą być również przekazywane przez wspólnoty religijne tworzone w celu wyznawania i szerzenia wiary religijnej. W świetle przepisów Konstytucji RP oraz ustawy o gwarancjach sumienia i wyznania takimi wspólnotami są kościoły i inne związki wyznaniowe, które korzystając ze swobody pełnienia funkcji religijnych mogą m.in. ustanawiać, kształcić i zatrudniać duchownych ${ }^{63}$. Z kolei w myśl przepisów ustawy o stosunku Państwa do gmin wyznaniowych żydowskich to gminy żydowskie dbają o zaopatrzenie w koszerną żywność oraz o ubój rytualny ${ }^{64}$. Uprawnienie do dokonywania uboju w sposób określony prawem religijnym oraz do nadzoru nad tym ubojem przysługuje zatem gminom ${ }^{65}$, które korzystają w tym zakresie z ochrony prawnej, znajdującej wyraz w możliwości dokonywania tych czynności zgodnie z prawem wewnętrznym. Na tle powyższych uwag rodzi się pytanie, czy w aspekcie podatkowym działalność prowadzona przez fundacje, jako instytucje prawa prywatnego służące realizacji celów użyteczności publicznej, może być traktowana na równi z działalnością związków wyznaniowych. Wydaje się, że odpowiedź na tak postawione pytanie winna być negatywna. Ustawa o zryczałtowanym podatku dochodowym stanowi jednoznacznie, że z ryczałtowej formy opodatkowania mogą korzystać wyłącznie osoby duchowne prawnie uznanych wyznań ${ }^{66}$. W związku z powyższym nasuwa się konkluzja, iż preferencja ta jest skierowana do osób pełniących funkcje duszpasterskie jako duchowni związków wyznaniowych. Ustawa o stosunku Państwa do gmin wyznaniowych żydowskich nie zawiera przepisów stwarzających podstawy prawne do ustanawiania przez wyznaniowe osoby prawne fundacji,

63 Art. 25 Konstytucji Rzeczypospolitej Polskiej z dnia 2 kwietnia 1997 r., Dz. U. z 1997 r. Nr 78, poz. 483 z późn. zm.; art. 2 pkt 1, art. 19 ust. 2 pkt 5 ustawy o gwarancjach wolności sumienia i wyznania.

64 Art. 9 ust. 2 ustawy o stosunku Państwa do gmin wyznaniowych żydowskich.

65 Zob. Brzozowski 2013, 49.

${ }^{66}$ Art. 2 ust. 2 ustawy o zryczałtowanym podatku dochodowym od osób fizycznych. 
które podlegałyby nadzorowi tych osób ${ }^{67}$. Nie przewiduje również żadnego szczególnego reżimu prawnego dla fundacji powołanej w celu przeprowadzania czynności związanych z koszeryzacją żywności. Jak już zaznaczono, fundacja ta jest fundacją prawa prywatnego, utworzoną na podstawie ustawy o fundacjach ${ }^{68}$, nad którą nadzór sprawują minister właściwy do spraw kultury i dziedzictwa narodowego oraz prezydent miasta stołecznego Warszawy ${ }^{69}$. Fundacje utworzone w powyższym trybie, nawet jeśli ich działalność wspomaga cele wyznaniowe, nie podlegają nadzorowi związku wyznaniowego i nie mogą być zaliczane do wyznaniowych żydowskich osób prawnych ${ }^{70}$. Nie są to zatem jednostki organizacyjne związku wyznaniowego o uregulowanej sytuacji prawnej. Powyższe skłania do konkluzji, iż fundacja mogłaby nawiązać stosunek pracy lub zawrzeć umowę cywilnoprawną z rabinem sprawującym nadzór nad ubojem rytualnym. Wypłacane na tej podstawie wynagrodzenie winno podlegać opodatkowaniu na zasadach ogólnych. Inaczej należałoby ocenić sytuację, w której wynagrodzenie za rzeczone czynności wypłacane byłoby przez gminy żydowskie. W takiej sytuacji o możliwości opodatkowania w formie zryczałtowanej przesądzałaby treść stosunku prawnego łączącego osoby duchowne z zatrudniającymi je wyznaniowymi osobami prawnymi. Jeżeli stosunek zobowiązaniowy wiążący duchownych z daną jednostką nie miałby charakteru pracowniczego, lecz osoby te prowadziłyby nadzór nad ubojem rytualnym na podstawie prawa wewnętrznego, to wynagrodzenie za wykonywanie związanych z tym nadzorem czynności mogłoby podlegać opodatkowaniu w formie ryczałtu od osób duchownych.

67 Podstawy prawne do tworzenia tego rodzaju fundacji statuuje art. 58 ustawy z dnia 17 maja 1989 r. o stosunku Państwa do Kościoła Katolickiego w Rzeczypospolitej Polskiej, tekst jedn. Dz. U. z 2019 r., poz. 1347.

68 Ustawa z dnia 6 kwietnia 1984 r. o fundacjach, tekst jedn. Dz. U. z 2018 r., poz. 1491.

69 Zob. wpis do Krajowego Rejestru Sądowego nr 91034.

70 W wyroku z dnia 19 marca 2009 r. (III CSK 265/08, Legalis nr 247643) SN orzekt, iż wyznaniowymi żydowskimi osobami prawnymi w rozumieniu ustawy o stosunku Państwa do gmin wyznaniowych żydowskich są tylko osoby wymienione w art. 5, 6, 22 tej ustawy. W ocenie Sądu charakter działalności, nawet pokrywający się z celami realizowanymi przez wyznaniowe żydowskie osoby prawne, nie ma znaczenia. 


\section{KONKLUZJE}

Przeprowadzona analiza prowadzi do następujących wniosków. Po pierwsze, w myśl przepisów ustawy o zryczałtowanym podatku dochodowym korzystanie $\mathrm{z}$ formy opodatkowania $\mathrm{w}$ postaci ryczałtu dla osób duchownych jest uzależnione od spełnienia trzech warunków materialnych, tj. posiadania statusu osoby duchownej prawnie uznanego wyznania, pełnienia funkcji o charakterze duszpasterskim oraz osiągania przychodów z opłat związanych ze sprawowaniem tych funkcji.

Po drugie, w świetle ustawy o gwarancjach wolności sumienia i wyznania status osoby duchownej na gruncie prawa polskiego ma osoba, która została ustanowiona duchownym zgodnie z normami prawa wewnętrznego kościoła lub innego związku wyznaniowego. Z treści Prawa wewnętrznego wyznaniowej wspólnoty żydowskiej w Rzeczypospolitej Polskiej wynika, że status duchownego przysługuje zarówno rabinom, jak i podrabinom, a zatem osoby te są także duchownymi w rozumieniu przepisów ustawy o zryczałtowanym podatku dochodowym.

Po trzecie, sprawowanie nadzoru nad ubojem rytualnym i obiektami produkcji, rozpowszechnianiem i konsumpcją żywności koszernej jest formą posługi religijnej. W konsekwencji wykonywanie powyższych czynności może być uznane za pełnienie funkcji o charakterze duszpasterskim w rozumieniu przepisów ustawy o zryczałtowanym podatku dochodowym.

Po czwarte, opodatkowaniu w formie ryczałtu od przychodów osób fizycznych podlegają przychody z opłat otrzymywanych w związku z pełnionymi funkcjami duszpasterskimi. Fundacje prawa prywatnego nie są wspólnotami religijnymi tworzonymi w celu wyznawania i szerzenia wiary religijnej. Wydaje się zatem, że mogą one zatrudniać osoby duchowne w ramach stosunku pracy lub stosunków cywilnoprawnych, a przekazywane na takiej podstawie prawnej wynagrodzenie winno podlegać opodatkowaniu na zasadach ogólnych. W sytuacji, w której wynagrodzenie za nadzór nad koszeryzacją żywności jest wypłacane przez jednostki organizacyjne związku wyznaniowego, opodatkowanie ryczałtem od osób duchownych wydaje się możliwe. Warunkiem jest jednak to, aby stosunek prawny wiążący osobę duchowną z daną jednostką nie miał charakteru pracowniczego, lecz wynikał z przepisów prawa wewnętrznego związku wyznaniowego. 


\section{BIBLIOGRAFIA}

Babiarz, Stefan. 2012. Ryczalty $w$ prawie podatkowym. Warszawa: LexisNexis, LEX.

Bartosiewicz, Adam, Ryszard Kubacki. 2011. Ustawa o zryczałtowanym podatku dochodowym od niektórych przychodów osiaganych przez osoby fizyczne. Komentarz. Warszawa: ABC, LEX.

Bielecki, Marek. 2018. „Status osoby duchownej w związku wyznaniowym «Świadkowie Jehowy w Polsce»". Studia z Prawa Wyznaniowego 21: 123-140.

Borszowski, Paweł. 2012. Ustawa o zryczaltowanym podatku dochodowym od niektórych przychodów osiaganych przez osoby fizyczne. Warszawa: LexisNexis, LEX.

Brzozowski, Wojciech. 2013. „Dopuszczalność uboju rytualnego w Polsce”. Państwo i Prawo 5: 47-56.

Dubisz, Stanisław. 2003. Uniwersalny słownik języka polskiego, t. 1. Warszawa: Wydawnictwo Naukowe PWN.

Dubisz, Stanisław. 2003. Uniwersalny słownik języka polskiego, t. 4. Warszawa: Wydawnictwo Naukowe PWN.

Dunaj, Bogusław. 1996. Słownik współczesnego języka polskiego, red. B. Dunaj. Warszawa: Wydawnictwo Wilga.

Dyda, Konrad. 2018. „Urząd proboszcza i wikariusza w kodyfikacjach prawa Kościoła łacińskiego". Przeglą Prawno-Ekonomiczny 44: 60-71.

Etel, Leonard. 2002. „Czy kościoły i księża płacą w Polsce podatki?”. Przegląd Podatkowy 6: 21-23.

Filak, Agnieszka. 2018. „Charakter prawny służby duchownego w Kościele Ewangelicko-Augsburskim w Rzeczypospolitej Polskiej”. Studia z Prawa Wyznaniowego 21: 141-155.

Gersdorf, Małgorzata. 2014. „Komentarz do art. 22”. W: Małgorzata Gersdorf, Michał Raczkowski, Krzysztof Rączka. Kodeks pracy. Komentarz. wyd. III. Warszawa: LexisNexis, LEX.

Gierasimiuk, Rafał Jerzy. 2005. „Opodatkowanie przychodów osób duchownych związanych z wykonywaniem funkcji o charakterze duszpasterskim". Zeszyty Naukowe Politechniki Białostockiej. Ekonomia i Zarządzanie 10: 161-172.

Huchla, Andrzej. 2001. Ustawa o zryczałtowanym podatku dochodowym od niektórych przychodów osiaganych przez osoby fizyczne. Komentarz. Biblioteka Podatkowa, LEX.

Jurowiec, Rafał. 2014. „Ewolucja opodatkowania dochodów osób duchownych”. Elpis 16: 215-220. 
Kaczmarczyk, Hubert Wojciech. 2014. „Zakaz uboju rytualnego w prawie polskim naruszeniem konstytucyjnego prawa do wolności religijnej?”. Przegląd Prawa Publicznego 12: 56-63.

Krzyżak, Lesław. 2015. „Ryczałtowe opodatkowanie osób duchownych”. Pedagogika Ojcostwa 2: 96-107.

Łętowska, Ewa, Monika Namysłowska, Mateusz Grochowski, Aneta Wiewiórowska-Domagalska. 2013a. „Prawo UE o uboju zwierząt i jego polska implementacja: kolizje interesów i ich rozwiązywanie (cz. I)”. Europejski Przegląd Sadowy 11: 13-18.

Łętowska, Ewa, Monika Namysłowska, Mateusz Grochowski, Aneta Wiewiórowska-Domagalska. 2013b. „Prawo UE o uboju zwierząt i jego polska implementacja: kolizje interesów i ich rozwiązywanie (cz. II)". Europejski Przegląd Sadowy 12: 4-9.

Nowicki, Marek Antoni. 2005. Nowy Europejski Trybunat Praw Człowieka. Wybór orzeczeń 1999-2004. Warszawa: Zakamycze.

Patyk, Jacek. 2008. Opodatkowanie Kościoła Katolickiego i osób duchownych, wyd. I. Toruń: Dom Organizatora.

Pieron, Bartłomiej. 2017. „Równe czy identyczne traktowanie osób duchownych w prawie polskim?" Annales Canonici 13: 155-181.

Porożyński, Jerzy. 2005. Opodatkowanie osób duchownych. Warszawa: RAABE.

Słowikowska, Anna. 2010. „Kompetencje koordynacyjne proboszcza. Wybrane zagadnienia". Roczniki Nauk Prawnych 2: 191-212.

Stanisławski, Tadeusz. 2001. „Ewolucja ryczałtowego sposobu opodatkowania przychodów osób fizycznych". Studia z Prawa Wyznaniowego 2: 67-79.

Stanisławski, Tadeusz. 2018. „Formy zatrudnienia duchownego w instytucjach kościelnych po II wojnie światowej”. Studia z Prawa Wyznaniowego 21: 239-254.

Stanisz, Piotr. 2011. „Sytuacja prawna osób duchownych”. W: Artur Mezglewski, Henryk Misztal, Piotr Stanisz, Prawo wyznaniowe. Warszawa: C.H. Beck.

Świto, Lucjan. 2010a. „Charakter prawny posługi duszpasterskiej proboszczów i wikariuszy w parafiach rzymskokatolickich w świetle prawa polskiego”. Seminare 27: 41-50.

Świto, Lucjan. 2010b. „Podatki a etyka obywatelska: opodatkowanie osób duchownych w Polsce". Forum Teologiczne 11: 97-111.

Walencik, Dariusz. 2008. „Zryczałtowany podatek dochodowy od przychodów osób duchownych. Wątpliwości interpretacyjne i postulaty de lege ferenda". Annales Canonici 4: 232-253.

Wojewoda-Buraczyńska, Katarzyna. 2017. „Opodatkowanie duchownych a bezpieczeństwo publiczne". W: Wolność sumienia $i$ religii a bezpieczeństwo 
i porzadek publiczny, red. Jerzy Nikołajew, Paweł Sobczyk, Konrad Walczuk, 165-174. Siedlce: Wydawnictwo Diecezji Siedleckiej UNITAS.

Zgółkowa, Halina (red.). 1996. Praktyczny słownik współczesnej polszczyzny, t. 9. Poznań: Wydawnictwo Kurpisz.

Zgółkowa, Halina (red.). 2002. Praktyczny słownik współczesnej polszczyzny, t. 35. Poznań: Wydawnictwo Kurpisz.

Zieliński, Robert. 2013. „Taxation of clergymen revenues from pastoral services”. Management and Business Administration. Central Europe 3: 98-113.

Zieliński, Tadeusz J. 2011. „Prawo wewnętrzne gmin wyznaniowych żydowskich w Polsce a normy ustawowe". Studia z Prawa Wyznaniowego 14: 25-45.

Zieliński, Tadeusz J. 2012. „Komentarz do art. 9”. W: Tadeusz J. Zieliński, Andrzej Czohara, Ustawa o stosunku państwa do gmin wyznaniowych żydowskich $w$ Polsce. Komentarz. Warszawa: Wolters Kluwer Polska, LEX. 